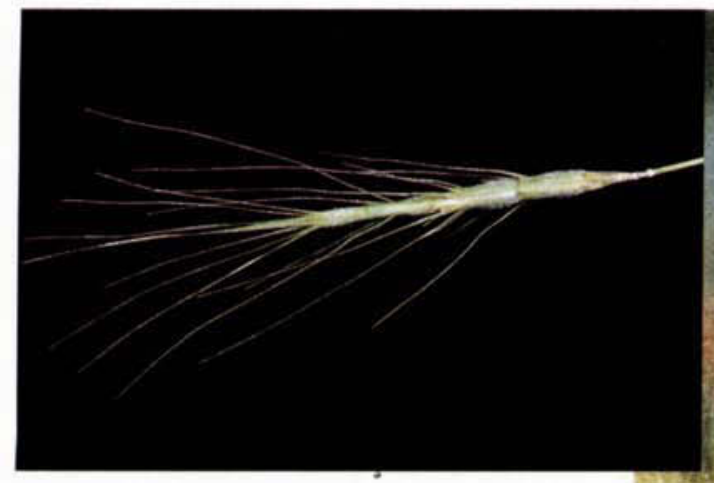

Barb goatgrass, above, was introduced in California around 1915. This noxious rangeland weed crowds out more valuable grass species, reduces forage quality and can cause mechanical injuries to livestock. Right, researchers at the UC Hopland Research and Extension Center tested the effectiveness of prescribed burns to control barb goatgrass.

\title{
Carefully timed burning can control barb goatgrass
}

\author{
Barb goatgrass is a noxious \\ annual grass that is rapidly \\ invading California's grassland \\ ecosystems. No effective \\ control strategies for managing \\ barb goatgrass have been \\ available that do not \\ simultaneously injure other \\ more desirable grass and \\ broadleaf species. In our study \\ at the UC Hopland Research \\ and Extension Center, we \\ conducted prescribed burning \\ in late spring or early summer \\ before barb goatgrass seeds \\ had reached maturation. One \\ year of prescribed burning was \\ not sufficient to control re- \\ establishment the following \\ year. However, 2 years of \\ complete burning gave effect- \\ ive control of barb goatgrass \\ while increasing native \\ perennial grass cover and \\ native species richness, par- \\ ticularly legumes. The success \\ of the goatgrass control was \\ directly proportional to the \\ completeness of the second- \\ year burn.
}

\author{
Joseph M. DiTomaso $\square$ Kerry L. Heise $\square$ Guy B. Kyser \\ Adina M. Merenlender $\sqcup$ Robert J. Keiffer
}

I hree species of goatgrass occur in California: jointed, ovate and barb goatgrass. All three species are winter annual grasses introduced early in the 20th century from Mediterranean Europe and western Asia. They are closely related to winter wheat (Triticum aestivum) and have been shown to hybridize with the cereal crop. In the Western states, jointed goatgrass is the most widespread species within the genus and is a serious problem for cereal crops, particularly winter wheat. Unlike jointed goatgrass, ovate (Aegilops ovata) and barb goatgrass are invasive primarily in disturbed and undisturbed grasslands and pastures.

Barb goatgrass ( $A$. triuncialis) was probably first introduced to California around 1915. From early records, it was reported to crowd out other valuable range species, reduce forage quality and quantity, and injure livestock when its barb awns (slender, bristlelike appendages with sharp "hooks") became lodged in their noses, mouths or eyes (Kennedy 1928). Once a grassland became infested with barb goatgrass, estimates indicated that livestock range capacity (the number of cattle the acreage can support) was reduced by $50 \%$ to $75 \%$ (Jacobsen 1929). By the late 1920s it had spread to thousands of acres, but the infestations were local and restricted to two counties, Calaveras and El Dorado (Talbot and Smith 1930). Despite its limited distribution, state and county officials made an effort to eradicate barb goatgrass. At that time, however, few options were available. Burning was used as a control measure, but prescribed burns were generally conducted either too early, when controlled fires were not sufficiently hot, or too late, when seedheads were more resistant to destruction. Consequently, burning as a control strategy was considered unreliable unless it was combined with a previous mowing or oil treatment (Talbot and Smith 1930).

The control efforts in the early part of the 20th century probably slowed the spread of barb goatgrass, which can rapidly move through livestock transfers and contaminate vehicles or 

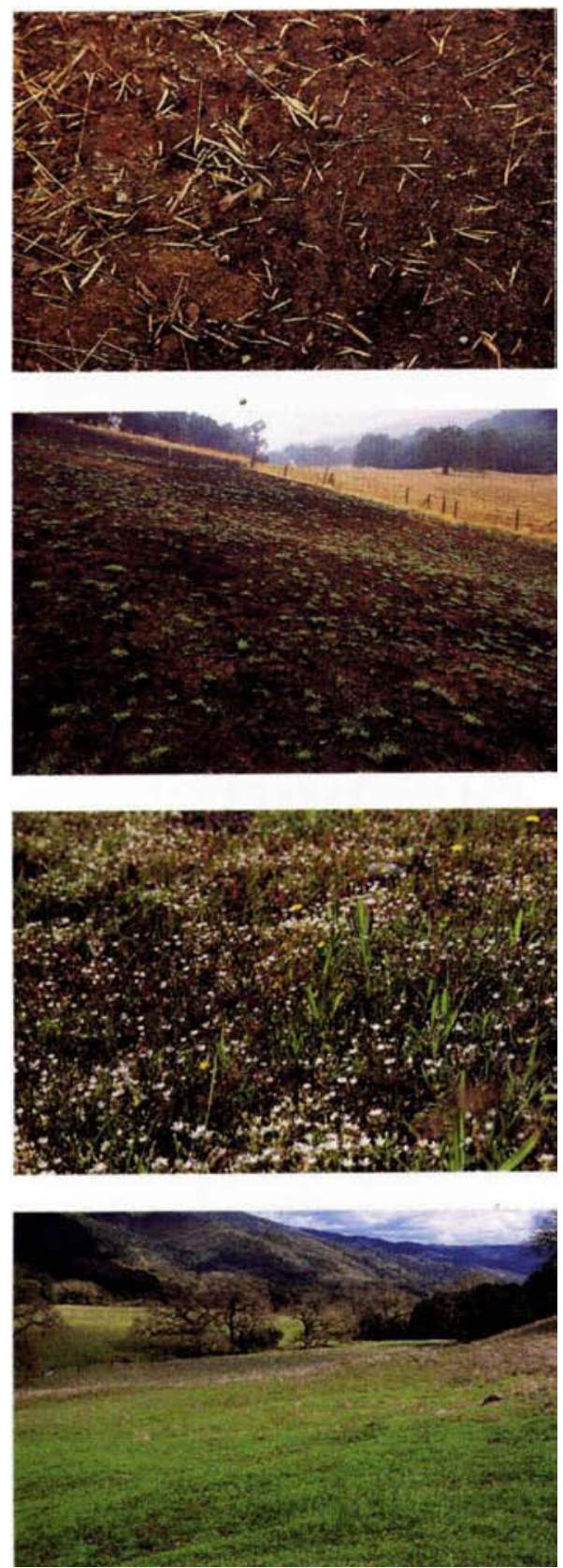

From top to bottom: Barb goatgrass seedheads remain on the soil surface after a prescribed burn; a native perennial grass (Hordeum brachyantherum) recovers rapidly; native forbs are prolific in the spring following the burn; 2 years later, barb goatgrass has been controlled on a Hopland pasture (unburned check plot can be seen in the background). equipment. Nevertheless, by 1973 it had expanded its range in the Central Valley and coastal foothills and was reported to occur in about 13 counties. By 1995, it had spread to 21 California counties (Peters et al. 1996). Today, barb goatgrass is a state-listed noxious weed in California and has also been listed as a noxious weed in Oregon, although it has not been reported there yet.

Despite 70 years of attempted management of barb goatgrass, no new effective control options were developed. Although many new herbicides are currently registered for use in grasslands and pastures, none provide selective control of barb goatgrass without damaging other desirable grasses (Peters et al. 1996). Burning remains potentially the most successful strategy, but little effort has been made to enhance its effectiveness with more-specific timing recommendations. Although not directed at barb goatgrass control, other studies using carefully timed burns have proved successful for native grassland restoration by reducing the cover of alien species while increasing the cover and diversity of native species (Menke 1992; Meyer and Schiffman 1999).

Many invasive and undesirable annual grasses, including barb goatgrass, medusahead (Taeniatherum caputmedusae) and ripgut brome (Bromus diandrus), have long barb awns that help facilitate their dispersal on clothing or on the hair, fur or wool of animals. To maximize the probability of dispersal, seeds (caryopses) remain attached on the inflorescence (flowering structures) much longer into the season than most desirable annual grass and broadleaf species. In medusahead, for example, Murphy and Lusk (1961) showed that seeds developed about 20 days after soft brome (Bromus hordeaceus), a more desirable annual grass.

Exposed seeds remaining attached to the culm (stem) are more vulnerable to grassland fires than are seeds on the soil surface. Studies on jointed goatgrass (A. cylindrica) demonstrated that seeds directly exposed to flame for more than 3 seconds did not germinate (Willis et al. 1988). By comparison, the studies showed that jointed goatgrass seed germinated following exposure to air heated to $392^{\circ} \mathrm{F}$ for nearly 1 minute. Prescribed burns in grasslands infested with yellow starthistle (Centaurea solstitialis) produced an average soil temperature of $392^{\circ} \mathrm{F}$, but the length of exposure to this temperature was too short to damage most of the seeds on the soil surface (DiTomaso et al. 1999). To control barb goatgrass while favoring the establishment of more desirable species, a prescribed burn must occur following seed dispersal and vegetative senescence (plant death) in desirable species, but before seed maturation and dispersal in barb goatgrass.

\section{Site factors and fire season}

In 1997 we initiated a barb goatgrass control study using timely prescribed burning at the UC Hopland Research and Extension Center (HREC) in Mendocino County. In this area, barb goatgrass has expanded its range and threatens livestock grazing operations and research activities on the facility. The objectives of this project were to reduce the levels of barb goatgrass, improve forage quality, increase total plant diversity on affected pastures and develop more effective control measures.

Two heavily infested barb goatgrass pastures were chosen for the study: Little Buck and South pastures. Little Buck pasture is a mix of three soil series: Climax, Laughlin and Sutherlin. Climax soils are fine-textured and moderately deep, and they have developed from partly metamorphosed basaltic rock. They are associated with the medium-textured soils of the Sutherlin and Laughlin series that have developed in sandstone and shale. Climax series soils are associated with good grass cover, while the Sutherlin and Laughlin series are typically associated with grasslands with a sparse oak cover.

Two areas of the South pasture 


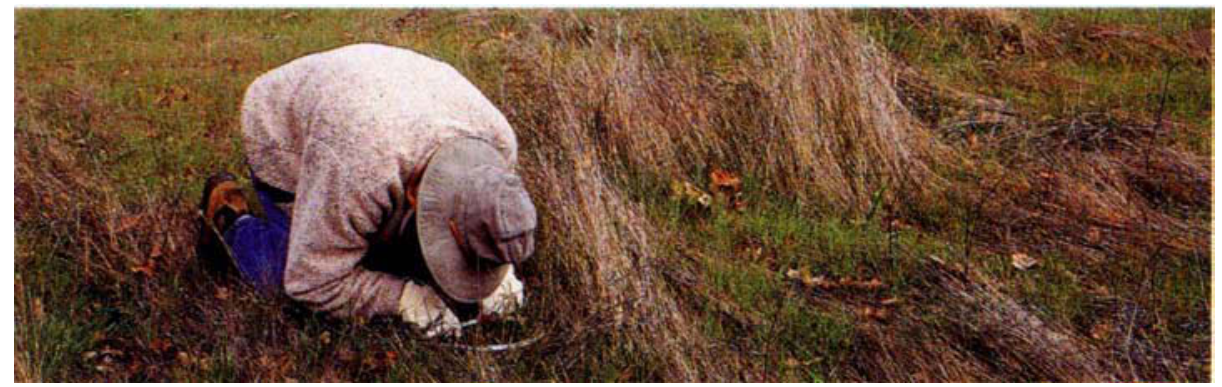

A single year of burning did not provide effective barb goatgrass control, but 2 years of carefully timed burns workéd well. Botanist Kerry Heise counts barb goatgrass seedlings at Hopland. were used in this study. The Upper

South pasture is composed of

Montara series soils, which are derived from serpentine rock and are shallow, stony and sparsely grasscomposed of soils of the Climax series, similar to Little Buck pasture.

A 3.7-acre area of Little Buck pasture and a 15.6-acre area of South pasture (across both Upper and Lower) were burned in May 1997 and July 1998 . The relative humidity was $7 \%$ to $57 \%$ (May 19, 1997) and 23\% (July 9, 1998) on burn days at Little Buck; and $30 \%$ to $65 \%$ (May 7,1997 ) and $23 \%$ to $28 \%$ (July 9,1998 ) at South pasture (Upper and Lower). A corresponding 5.5 and 7.3 acres of Little Buck and South pastures, respectively, were used as unburned controls. Timing of the burns corresponded to phenology of the barb goatgrass population, which varied dramatically depending on seasonal climatic conditions. During the rainy season of 1996 and 1997, only $15 \%$ ( $17 \mathrm{~cm} ; 6.7$ inches) of the total seasonal precipitation occurred after January (fig. 1). In contrast, $65 \%$ ( $98 \mathrm{~cm} ; 37.4$ inches) of the seasonal rainfall occurred after January in the 1997-1998 season. This late-season precipitation slowed the development covered. The Lower South pasture is of barb goatgrass and other desirable grasses in 1998 compared with 1997, delaying the timing of the burn.

Five soil core samples ( 2 inches in diameter) were collected from each site in May 1997 and just after the burn in 1998. Analysis conducted at the HREC laboratory demonstrated no $\mathrm{pH}$ differences and little organic matter and nitrogen differences between the sites in 1997 before the burn and in 1998 after a single year of prescribed burning (table 1). The only statistical difference between the South pasture sites was a higher percent of organic matter and nitrogen in the lower burn area compared with the unburned control site in 1997 prior to the burn. No significant year-to-year differences were measured in either the unburned or burned areas.

We established five permanent 100 -foot line transects in each unburned control and in the burned sites of both pastures. We recorded our observations of plant species intercepting each of 50 points (at 2-foot intervals) along the transects. Vegetative cover (percent of groundcover) and species richness (number of species intercepted) were calculated from the

\section{Barb goatgrass control}

\begin{tabular}{|c|c|c|c|c|c|c|c|}
\hline \multirow[b]{2}{*}{ Pasture } & \multirow[b]{2}{*}{ e Treatment } & \multirow{2}{*}{$\begin{array}{r}\text { pH } \\
1997 \\
\end{array}$} & \multicolumn{2}{|c|}{ Organic matter $(\%)$} & \multirow[b]{2}{*}{1998} & \multicolumn{2}{|c|}{ Nitrogen (\%) } \\
\hline & & & 1998 & 1997 & & 1997 & 1998 \\
\hline \multirow[t]{3}{*}{ South } & Unburned & $7.06 \pm 0.21 a$ & $6.84 \pm 0.11 a$ & $12.3 \pm 1.5 b$ & $14.7 \pm 1.7 \mathrm{a}$ & $0.11 \pm 0.07 b$ & $0.13 \pm 0.03 a$ \\
\hline & Lower burn & $7.18 \pm 0.23 a$ & $6.82 \pm 0.19 a$ & $14.3 \pm 1.3 a$ & $14.1 \pm 2.6 \mathrm{a}$ & $0.18 \pm 0.03 a$ & $0.18 \pm 0.08 a$ \\
\hline & Upper burn & $7.14 \pm 0.11 \mathrm{a}$ & $6.72 \pm 0.13 a$ & $13.5 \pm 1.1 \mathrm{ab}$ & $15.1 \pm 1.6 \mathrm{a}$ & $0.11 \pm 0.05 a b$ & $0.16 \pm 0.07 a$ \\
\hline Little & Unburned & $6.16 \pm 0.49 a$ & $6.04 \pm 0.45 a$ & $8.9 \pm 3.0 \mathrm{a}$ & $9.8 \pm 3.7 \mathrm{a}$ & $0.18 \pm 0.04 a$ & $0.18 \pm 0.08 a$ \\
\hline Buck & Burned & $6.62 \pm 0.47 a$ & $6.30 \pm 0.60 a$ & $11.4 \pm 1.4 \mathrm{a}$ & $13.4 \pm 4.7 a$ & $0.19 \pm 0.04 a$ & $0.24 \pm 0.13 a$ \\
\hline
\end{tabular}

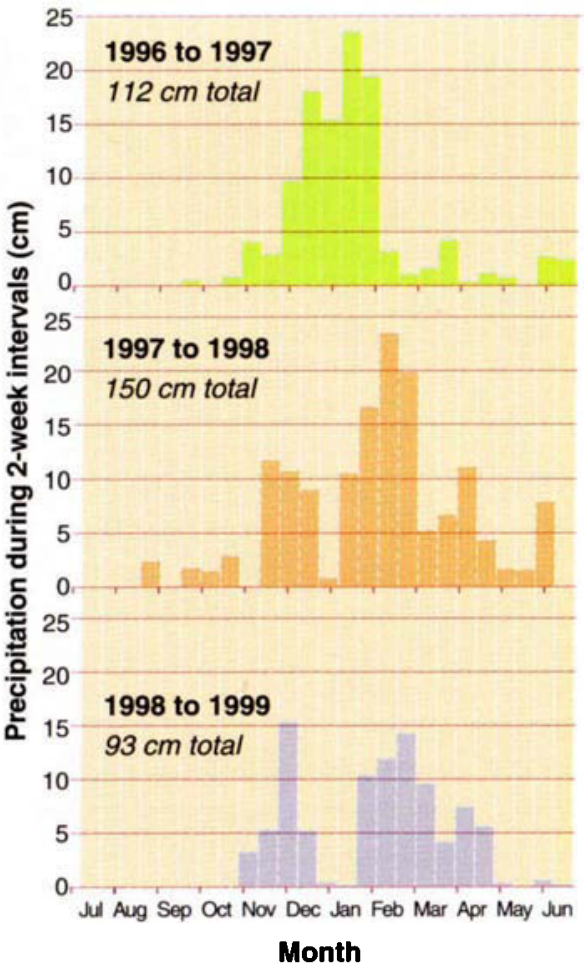

Fig. 1. Precipitation at HREC from 1996 to 1999.

point-intercept data. Point-intercept transects were conducted in May or June before the burns. We used the same transects to determine the completeness of the burns in the second year. This measure was defined as the percent of the line transect that was burned. For seed counts, two soil cores ( 2 inches in diameter and 2 inches deep) were randomly collected along each transect after the seeds dispersed in fall for a total of 10 samples per treatment (1997 and 1999 only). We counted seeds following extraction with a water/air elutriator, which separates seeds from soil to allow accurate evaluation of seed counts. Seedling counts were made in March or April (1998 and 1999 only) by randomly tossing a 7.9-inch (20 centimeter)-diameter ring within 3.28 feet (1 meter) of the permanent transects (5 samples per transect; 25 samples per treatment). Both seed and seedling densities are presented as numbers per square foot. We analyzed the data using ANOVA followed by Fisher's protected LSD test. To estimate change in percent frequency in individual species, four 2.7-square-foot quadrats 
TABLE 3a. Vegetative cover $(\%)$ at HREC upper and lower South pasture, before and after prescribed burns*

\begin{tabular}{|c|c|c|c|c|c|c|c|c|c|}
\hline \multirow[b]{2}{*}{ Vegetation type } & \multicolumn{3}{|c|}{ Unburned } & \multicolumn{3}{|c|}{ Lower burn } & \multicolumn{3}{|c|}{ Upper burn } \\
\hline & 1997 & -1998 & 1999 & 1997 & 1998 & 1999 & 1997 & 1998 & 1999 \\
\hline $\begin{array}{l}\text { Grasses } \\
\text { (introduced annuals) }\end{array}$ & $36 \pm 15 b$ & $90 \pm 26 a$ & $89 \pm 30 a$ & $87 \pm 13 a$ & $85 \pm 20 a$ & $81 \pm 8 a$ & $78 \pm 13 a$ & $54 \pm 14 a b$ & $22 \pm 7 b$ \\
\hline (native perennials) $\dagger$ & 0 & $1 \pm 2$ & $2 \pm 3$ & 0 & 0 & 0 & 0 & 0 & 0 \\
\hline Total grasses & $43 \pm 24 b$ & $91 \pm 24 a$ & $91 \pm 27 a$ & $93 \pm 19 a$ & $85 \pm 20 a$ & $81 \pm 8 a$ & $82 \pm 14 a$ & $57 \pm 15 a b$ & $23 \pm 9 b$ \\
\hline Total plant cover & $59 \pm 9 c$ & $103 \pm 23 a b c$ & $104 \pm 24 a b c$ & $109 \pm 22 a b$ & $146 \pm 21 a$ & $123 \pm 17 \mathrm{ab}$ & $121 \pm 32 a b$ & $86 \pm 29 b c$ & $58 \pm 21 c$ \\
\hline
\end{tabular}

- Mean values \pm standard deviation. Across each row, values followed by the same letters are not different $(P=0.05)$. Means compared using ANOVA followed by

Fisher's protected LSD test.

$\dagger$ No significant differences.

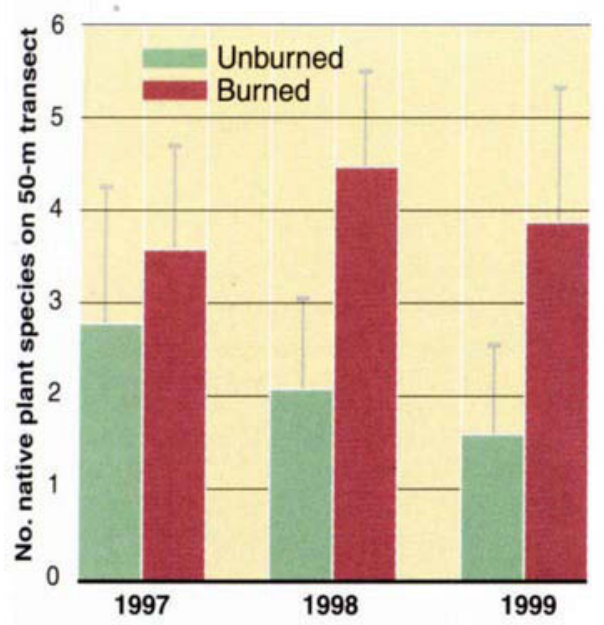

Fig. 4. Transect counts of native plant species in burned and unburned sites at Little Buck and Upper South pastures in 1997 (preburn), 1998 and 1999. Values represent average number of native species contacted using point method along line transects ( 50 points per transect). Lines above bars represent one standard deviation from mean values.

lings after a second year of control suggests that seeds do not survive more than 2 years in the soil.

\section{Vegetation changes}

In California, suppression of periodic fire has dramatically changed the composition of rangelands. For noxious annuals such as barb goatgrass, medusahead, ripgut brome and yellow starthistle, fire suppression can lead to their dominance in grasslands. Reintroduction of timed burns to rangelands can remove litter, recycle nutrients, stimulate tillering (the emergence of shoots from the base of the plant) in perennial grasses and reduce noxious annual grass or broadleaf weed

TABLE 3b. Vegetative cover $(\%)$ at HREC Little Buck pasture, before and after prescribed burns*

\begin{tabular}{|c|c|c|c|c|c|c|}
\hline \multirow[b]{2}{*}{ Vegetation type } & \multicolumn{3}{|c|}{ Unburned } & \multicolumn{3}{|c|}{ Burned } \\
\hline & 1997 & 1998 & 1999 & 1997 & 1998 & 1999 \\
\hline $\begin{array}{l}\text { Grasses } \\
\text { (introduced annuals) }\end{array}$ & $126 \pm 18 a$ & $152 \pm 36 a$ & $149 \pm 35 a$ & $115 \pm 27 a$ & $164 \pm 19 a$ & $58 \pm 23 b$ \\
\hline (native perennials) $\dagger$ & 0 & 0 & $1 \pm 2$ & $1 \pm 2$ & $9 \pm 18$ & $10 \pm 18$ \\
\hline Total grasses & $127 \pm 17 a b$ & $156 \pm 35 a b$ & $152 \pm 34 a b$ & $116 \pm 27 b c$ & $173 \pm 28 a$ & $68 \pm 11 \mathrm{ca}$ \\
\hline Total plant cover & $35 \pm 17 \mathrm{bcd}$ & $202 \pm 46 a$ & $173 \pm 43 a$ & $126 \pm 28 \mathrm{~cd}$ & $198 \pm 39 a b$ & $79 \pm 15 d$ \\
\hline
\end{tabular}

seedbanks. In addition, fire has been shown to be beneficial to the maintenance of perennial bunchgrass populations and other native broadleaf species, particularly native legumes such as clovers (Trifolium spp.), Gambel's locoweed (Astragalus gambelianus) and Wrangel's trefoil (Lotus wrangelianus) (DiTomaso et al. 1999).

In general, the cover of introduced, native and total forbs did not change significantly over the 3-year period (data not shown). However, vegetative cover analysis indicated a consistent reduction in introduced annual grasses following the second burn in both Little Buck and Upper South pastures (tables $3 a$ and $3 b$ ). As a result, total plant cover was also lower in these two sites compared with the adjacent unburned areas. The reduction in introduced grasses and total vegetative cover was primarily due to the decrease in barb goatgrass. Very few native perennial grasses were present in either the unburned or burned areas of the South pasture.

When data from the unburned sites were combined, the average number of native plant species encountered in the line transects gradually declined from 1997 to 1999 (fig. 4). When the data from the burned sites in Upper South and Little Buck pastures were combined, the average number of native species per line transect before the burn was slightly, but not significantly greater $(28 \%)$ than the unburned site. The native species values were significantly greater in the burned sites compared with the unburned areas after both the first (113\% greater) and second (139\% greater) year of prescribed burning (table 4 ).

From the indicator species analysis, the frequency of the introduced species barb goatgrass, hedgehog dogtailgrass (Cynosurus echinatus), and Malta starthistle or tocalote (Centaurea melitensis) declined with the prescribed burn regime, although in the case of hedgehog dogtailgrass and Malta starthistle population differences were not significant. Interestingly, soft brome significantly decreased in both the burned and unburned sites at Upper South and Little Buck pastures. By comparison, several native species increased significantly, including a native sandwort (Minuartia californica) and three native legume species (Trifolium bifidum, Astragalus gambelianus and Lotus

humistratus). Similar increases in le- 


\begin{tabular}{|c|c|c|c|c|c|c|}
\hline \multicolumn{7}{|c|}{$\begin{array}{l}\text { TABLE 4. Frequency (\%) of common species in Little Buck } \\
\text { and Upper South pastures in 1997, } 1998 \text { and } 1999^{*}\end{array}$} \\
\hline \multirow[b]{2}{*}{ Speciest } & \multicolumn{3}{|c|}{ Unburned } & \multicolumn{3}{|c|}{ Burn } \\
\hline & 1997 & 1998 & 1999 & $\begin{array}{l}1997 \\
\text { Preburn }\end{array}$ & $\begin{array}{c}1998 \\
1 \text { yr. burn }\end{array}$ & $\begin{array}{c}1999 \\
2 y r . \text { burn }\end{array}$ \\
\hline $\begin{array}{l}\text { Little Buck pasture } \\
\text { Barb goatgrass } \\
\text { (Aegilops triuncialis) (I) }\end{array}$ & 80 & 85 & 85 & $100 a$ & $95 a$ & Obๆ \\
\hline $\begin{array}{l}\text { Clover } \\
\text { (Trifolium bifidum) }(\mathrm{N})\end{array}$ & 5 & 5 & 0 & $15 a \ddagger$ & $25 b$ & $35 b$ \\
\hline $\begin{array}{l}\text { Hedgehog dogtailgrašs } \\
\text { (Cynosurus echinatus) (I) }\end{array}$ & 35 & 50 & 70 & 20 & 20 & 0 \\
\hline $\begin{array}{l}\text { Meadow barley } \\
\text { (Hordeum brachyantherum) }(\mathrm{N})\end{array}$ & 0 & 0 & 0 & 5 & 10 & 20 \\
\hline $\begin{array}{l}\text { Soft brome } \\
\text { (Bromus hordeaceus) (1) }\end{array}$ & $60 a$ & $55 a b$ & 10b9ी & $100 a$ & $20 a$ & $5 \mathrm{~b} 9$ \\
\hline $\begin{array}{l}\text { Subterranean clover } \\
\text { (Trifolium subterraneum) (I) }\end{array}$ & 10 & 25 & 0 & $45 \mathrm{a} \S$ & $50 \mathrm{~b}$ & $55 b$ \\
\hline $\begin{array}{l}\text { Upper South pasture } \\
\text { Barb goatgrass } \\
\text { (Aegilops triuncialis) (I) }\end{array}$ & 100 & 100 & 100 & $100 a$ & $95 a$ & $25 \mathrm{~b}$ ๆ \\
\hline $\begin{array}{l}\text { California sandwort } \\
\text { (Minuartia californica) (N) }\end{array}$ & 50 & 60 & 45 & $22 a \emptyset$ & $55 b$ & $65 b$ \\
\hline $\begin{array}{l}\text { Gambel's locoweed } \\
\text { (Astragalus gambelianus) (N) }\end{array}$ & 0 & 0 & 0 & $11 a$ & $40 a b$ & $70 \mathrm{bt}$ \\
\hline $\begin{array}{l}\text { Malta starthistle } \\
\text { (Centaurea melitensis) (I) }\end{array}$ & 25 & 65 & 50 & 45 & 55 & 5 \\
\hline $\begin{array}{l}\text { Soft brome } \\
\text { (Bromus hordeaceus) (I) }\end{array}$ & $75 a \S$ & $45 b$ & $15 b$ & $78 \mathrm{a}$ & $10 \mathrm{~b}$ & $40 \mathrm{~b}$ \\
\hline $\begin{array}{l}\text { Trefoil } \\
\text { (Lotus humistratus) (N) }\end{array}$ & 100 & 30 & 25 & 11af & $55 \mathrm{~b}$ & $65 b$ \\
\hline $\begin{array}{l}\text { Across each row within the burn or } \\
\text { frequency values without letters fo } \\
\text { indicator species analysis. }\end{array}$ & $\begin{array}{l}\text { ourn } \\
\text { h tre }\end{array}$ & $s$ fo & $\begin{array}{l}\text { diffe } \\
\text { llys } s\end{array}$ & $\begin{array}{l}\text { lers a } \\
\text { th }(\mathrm{P} \text {; }\end{array}$ & $\begin{array}{l}\text { cantly diff } \\
\text { llues com }\end{array}$ & $\begin{array}{l}\text { int. Species } \\
\text { red using }\end{array}$ \\
\hline$+\mathrm{I}=$ introduced; $\mathrm{N}=$ native & 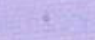 & & & & & \\
\hline$\ddagger$ Statistically significant at $P=0.20$. & & & & & & \\
\hline$\S$ Statistically significant at $P=0.10$. & & & & & & \\
\hline I Statistically significant at $\mathrm{P}=0.05$. & & & & & & \\
\hline
\end{tabular}

gumes were also measured when prescribed burning was used to control yellow starthistle (DiTomaso et al. 1999).

\section{Two good burns}

Based on these results, two consecutive years of prescribed burning can be an effective tool for barb goatgrass control. In addition, timely prescribed burning can also enhance the population of several native plant species, particularly perennial grasses and legumes. It is important to note, however, that unless two consecutive years of complete burning can be achieved at the appropriate times, this invasive annual grass will not be completely controlled.

\section{Control maintained 3 years later}

Vegetative cover of barb goatgrass and other species in both Little Buck and South pastures was revisited and evaluated in June 2001, 3 years after the last burn in this study. In Little Buck pasture, which burned completely in both 1997 and 1998, barb goatgrass represents only $5 \%$ of the total cover compared with $35 \%$ in the adjacent unburned site. Without further management efforts, the level of control is still $85 \%$. The native perennial grass population that increased after the burn in Little Buck pasture continues to be considerably higher ( $8 \%$ cover) than in the unburned area (1\%). In Lower South pasture, where the second-year burn was incomplete, barb goatgrass was nearly the same ( $42 \%$ cover) as that in the adjacent unburned area $(57 \%$ cover). In Upper South pasture, which burned more completely in the second year, barb goatgrass cover in 2001 (26\%) was about $55 \%$ less than in the unburned site. These updated results indicate that two consecutive years of successful prescribed burning can provide continued control of barb goatgrass for at least a couple of years after treatment. - J.D. et al.

J.M. DiTomaso is Extension Weed Specialist, UC Davis; K.L. Heise is Botanist and Staff Research Associate, UC Integrated Hardwood Range Management Program; G.B. Kyser is Staff Research Associate, Department of Vegetable Crops, UC Davis; A.M. Merenlender is Extension Specialist, Department of Environmental Science, Policy, and Management, UC Berkeley; and R.J. Keiffer is Principal Superintendent of Agriculture, HREC. We thank Charles Vaughn for conducting the soil analyses, the UC Integrated Hardwood Range Management Program for its support and the HREC Research Advisory Committee for appropriating necessary land and staff support. 


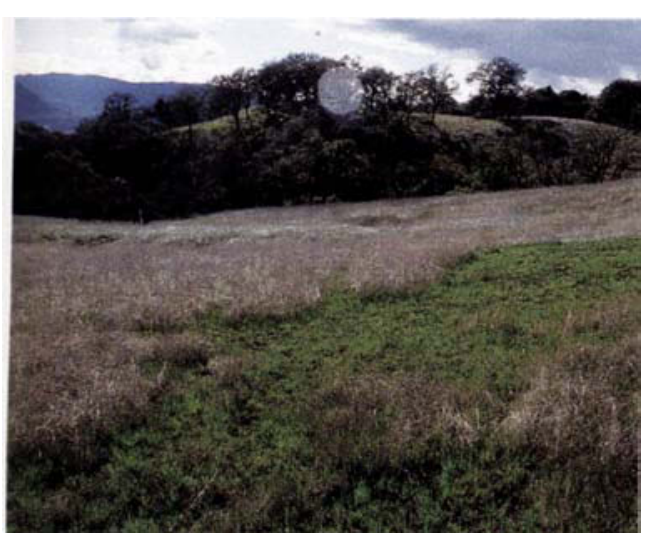

In addition to controlling noxious annual weeds, prescribed burns on rangeland can remove litter, recycle nutrients and stimulate the emergence of desirable perennial grasses.

\section{References}

DiTomaso JM, Kyser GB, Hastings MS. 1999. Prescribed burning for control of yellow starthistle (Centaurea solstitialis) and enhanced native plant diversity. Weed Sci 47(2):233-42.

Donald WW. 1991. Seed survival, germination ability, and emergence of jointed goatgrass (Aegilops cylindrica). Weed Sci 39(2):210-6.

Hopkinson P, Fehmi JS, Bartolome JW, et al. 1999. Adaptive management and fire control of barb goatgrass. Res Manage Notes 17(3): 168-9.

Jacobsen WC. 1929. Goatgrass - A weed pest of the range. Monthly Bull, Calif Dept Agr 18(1):37-41.

Kennedy PB. 1928. Goatgrass or wild wheat (Aegilops triuncialis). J Am Soc Agr 20(12):1292-6.

Ludwig JA, Reynolds JF. 1988. Statistical Ecology. New York: J Wiley. $337 \mathrm{p}$.

Menke JW. 1992. Grazing and fire management for native perennial grass restoration in California grasslands. Fremontia 20(12):22-5.

Meyer MD, Schiffman PM. 1999. Fire season and mulch reduction in a California grassland: A comparison of restoration strategies. Madroño 46(1):25-7.

Murphy AH, Lusk WC. 1961. Timing medusahead burns to destroy more seed and save good grasses. Cal Ag 15(11):6-7.

Peters A, Johnson DE, George MR. 1996. Barb goatgrass: $A$ threat to California rangelands. Rangelands 18(1):8-10.

Talbot MW, Smith LS. 1930. The goatgrass situation in California. Monthly Bull, Calif Dept Agr 19(1):40-6.

Willis BD, Evans JO, Dewey SA. 1988. Effects of temperature and flaming on germinability of jointed goatgrass (Aegilops cylindrica Host) seed. Proc West Soc Weed Sci 41:49-55.

Young FL, Ogg AG Jr, Dotray PA. 1990. Effect of postharvest field burning on jointed goatgrass (Aegilops cylindrica) germination. Weed Tech 4(1):123-7.

\section{Animals and fungi can affect goatgrass establishment}

Valerie T. Eviner

\section{F. Stuart Chapin III}

$\mathrm{T}$ he establishment of barb goatgrass is greatly affected by its interactions with other species in California grassland. For example, goatgrass
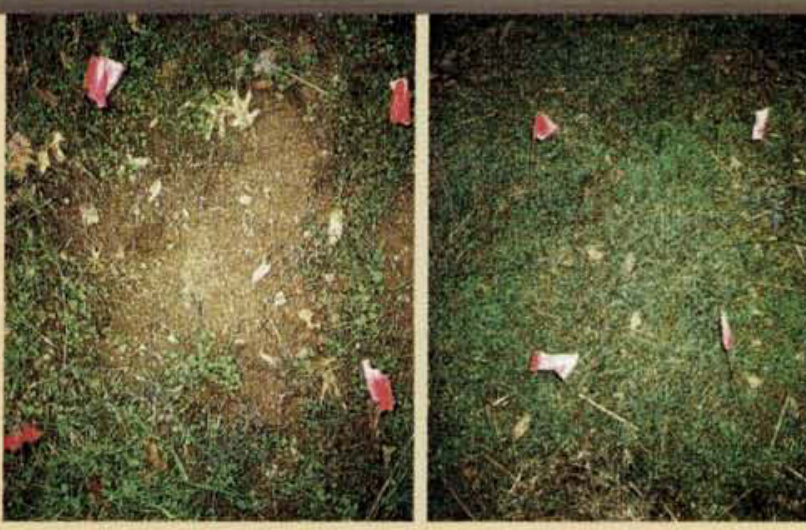
establishment is enhanced by a fungus, Ulocladium atrum. This fungus is visible as black lesions on the surface of the seedhead; it helps break down the tough, woody seedhead surrounding goatgrass seeds. This speeds up germination and leads to a $65 \%$ increase in goatgrass biomass at the end of the growing season.

In contrast, small mammals help to slow goatgrass invasion. In two separate experiments, more than 3,000 individually marked goatgrass seedheads were laid out in plots at the UC Hopland Research and Extension Center (HREC). Within days, new rodent holes had formed in the areas where the seeds were planted, and every single seedhead was missing. It was not determined if this predation was due to mice or voles.

Gophers have a dramatic effect on goatgrass establishment. We established 10.76-square-foot plots of eight different plant species commonly found in California annual grassland at HREC. There were 18 replicate plots of each species randomly distributed throughout the study area. Gophers selectively built mounds in goatgrass plots, completely burying the goatgrass and killing most of the seedlings. Gophers buried every goatgrass plot, while only a
Controlling gophers on rangeland can have an unintended side effect: dramatically increased establishment of barb goatgrass. In experiments at Hopland, gophers selectively disturbed goatgrass plots, burying almost all the seedlings, left, while goatgrass plots protected from gophers have dense seedling establishment.

handful of other plots had significant levels of gopher disturbance. Goatgrass biomass was 3.5 times higher in gopher exclosures than in the presence of gophers. A preliminary survey of the pastures at HREC indicated that where gophers were present, goatgrass

coexists with other plant species, while in areas without gopher activity, goatgrass formed a dense monoculture stand.

While much more research is needed to determine the relative importance of the fungus Ulocladium, mice and voles, gophers and competition with plants on goatgrass establishment, it is clear that these interactions can play a significant role in the establishment of this invasive species.

V.T. Eviner is Ph.D. Candidate, Department of Integrative Biology, UC Berkeley; and F.S. Chapin III is Professor, Institute of Arctic Biology, University of Alaska, Fairbanks. 